\title{
Eptifibatide and abciximab inhibit insulin-induced focal adhesion formation and proliferative responses in human aortic smooth muscle cells
}

\author{
Alokkumar Pathak ${ }^{1}$, Renyi Zhao ${ }^{1}$, Jianhua Huang ${ }^{1}$ and George A Stouffer*1,2
}

Address: ${ }^{1}$ Carolina Cardiovascular Biology Center, University of North Carolina, Chapel Hill, NC, USA and ${ }^{2}$ Division of Cardiology, University of North Carolina, Chapel Hill, NC, USA

Email: Alokkumar Pathak - pathaka@med.unc.edu; Renyi Zhao - Renyi_Zhao@med.unc.edu; Jianhua Huang - jianhuahuang33@hotmail.com; George A Stouffer* - rick_stouffer@med.unc.edu

* Corresponding author

Published: 23 December 2008

Cardiovascular Diabetology 2008, 7:36 doi:10.1 186/1475-2840-7-36

This article is available from: http://www.cardiab.com/content/7///36

(C) 2008 Pathak et al; licensee BioMed Central Ltd.

This is an Open Access article distributed under the terms of the Creative Commons Attribution License (http://creativecommons.org/licenses/by/2.0), which permits unrestricted use, distribution, and reproduction in any medium, provided the original work is properly cited.
Received: 16 October 2008

Accepted: 23 December 2008

\begin{abstract}
Background: The use of abciximab (c7E3 Fab) or eptifibatide improves clinical outcomes in diabetics undergoing percutaneous coronary intervention. These $\beta_{3}$ integrin inhibitors antagonize fibrinogen binding to $\alpha_{11 b} \beta_{3}$ integrins on platelets and ligand binding to $\alpha_{v} \beta_{3}$ integrins on vascular cells. $\alpha_{v} \beta_{3}$ integrins influence responses to insulin in various cell types but effects in human aortic smooth muscle cells (HASMC) are unknown.
\end{abstract}

Results and discussion: Insulin elicited a dose-dependent proliferative response in HASMC. Pretreatment with m7E3 (an anti- $\beta_{3}$ integrin monoclonal antibody from which abciximab is derived), c7E3 or LM609 inhibited proliferative responses to insulin by $81 \%, 59 \%$ and $28 \%$, respectively. Eptifibatide or cyclic RGD peptides completely abolished insulin-induced proliferation whereas tirofiban, which binds $\alpha_{1 \mathrm{lb}} \beta_{3}$ but not $\alpha_{\mathrm{v}} \beta_{3}$, had no effect. Insulin-induced increases in c-Jun $\mathrm{NH}_{2}$-terminal kinase-I (JNKI) activity were partially inhibited by m7E3 and eptifibatide whereas antagonism of $\alpha_{v} \beta_{3}$ integrins had no effect on insulin-induced increases in extracellular signalregulated kinase (ERK) activity. Insulin stimulated a rapid increase in the number of vinculincontaining focal adhesions per cell and treatment with $\mathrm{m7E3}$, c7E3 or eptifibatide inhibited insulininduced increases in focal adhesions by $100 \%, 74 \%$ and $73 \%$, respectively.

Conclusion: These results demonstrate that $\alpha_{v} \beta_{3}$ antagonists inhibit signaling, focal adhesion formation and proliferation of insulin-treated HASMC.

\section{Background}

Individuals with insulin resistance states and elevated levels of circulating insulin, the prototype of which is type II diabetes, are more prone to develop vascular disease and less likely to benefit from available treatments compared to non-diabetic individuals[1]. Abciximab and eptifibatide, two widely used integrin inhibitors, improve mor- tality in diabetics undergoing percutaneous coronary intervention (PCI). In a pooled analysis of three large clinical trials, abciximab was associated with a $44 \%$ reduction in one year mortality in diabetics $(4.5 \%$ in patients receiving placebo and $2.5 \%$ in patients receiving abciximab)[2]. Similarly, eptifibatide was associated with a reduction in one year mortality in diabetics $3.5 \%$ in patients receiving 
placebo and $1.3 \%$ in patients receiving eptifibatide) in the Enhanced Suppression of the platelet IIb/IIIa Receptor with Integrilin Therapy (ESPRIT) trial[3].

Abciximab and eptifibatide, in addition to inhibiting platelet aggregation via antagonism of fibrinogen binding to $\alpha_{\mathrm{IIb}} \beta_{3}$ integrins, also antagonize ligand binding to $\alpha_{v} \beta_{3}$ integrins on vascular cells $[4,5]$. Recent studies in cultured cells have revealed considerable cross-talk between $\alpha_{v} \beta_{3}$ integrins and insulin receptor-mediated signals. Vuori and Ruoslahti[6] found that $\alpha_{v} \beta_{3}$ integrins associate with insulin-receptor substrate-1 (IRS-1), a docking protein that phosphorylates on tyrosine following insulin-receptor activation and binds $\mathrm{SH} 2$ domain-containing proteins that propagate the insulin signal. Moreover, $\alpha_{v} \beta_{3}$ integrins associated with tyrosine phosphorylated insulin receptors and other, as yet unidentified, tyrosine phosphorylated proteins in insulin-treated fibroblasts[7]. These associations were specific for $\alpha_{v} \beta_{3}$ integrins and proliferative responses to insulin were enhanced by extracellular matrices that ligated $\alpha_{\mathrm{v}} \beta_{3}$ integrins. More recently, Lopez-Alemany et al. reported that plasminogen activator inhibitor-1 (PAI1) competes with $\alpha_{\mathrm{v}} \beta_{3}$ integrins for binding to vitronectin and by this mechanism blocks insulin-induced migration in NIH3T3 cells and human umbilical vein endothelial cells[8].

Given the important role of smooth muscle cell (SMC) proliferation in atherosclerosis progression and in revascularization failures, the present studies were performed to explore the hypothesis that abciximab and eptifibatide inhibit proliferative responses of human aortic SMC (HASMC) to insulin via antagonizing $\alpha_{v} \beta_{3}$ integrins.

\section{Methods \\ Cell culture, proliferation assays and flow cytometric analysis}

HASMC were obtained from Clonetics (San Diego, CA) and maintained in culture as previously described[4]. SMC between passages 4 and 15 were used in these studies. The cells were grown in media that was a 1:1 mixture of regular DMEM and smooth muscle proliferation medium with a glucose concentration of $15.27 \mathrm{mM}$. Cell proliferation, flow activated cell sorting (FACS) analysis, apoptosis assays, focal adhesion assays and cell adhesion assays were performed as previously described $[4,9]$.

\section{Reagents}

m7E3 and c7E3 Fab were provided by Centocor (Malvern, $\mathrm{Pa}$ ). Eptifibatide was provided by Cor Therapeutics (South San Francisco, CA). Insulin and peptide integrin inhibitors were purchased from Sigma (St. Louis, MO).

\section{Transfection and selection of stable $\beta_{3}$ integrin expressing HEK cells}

pcDNA-1 neo constructs encoding full-length $\beta_{3}$ subunits were a gift of $D$. Cheresh (Scripps Research Institute, La
Jolla, CA) and have been previously described[10]. $\beta_{3}$ integrin-deficient HEK 293 cells (ATCC; Manassas, VA) were transfected using the FuGENE Transfection Reagent (Boehringer Mannheim) and stable cell lines established as previously described[5].

\section{JNKI kinase activity assay}

HASMC were grown to subconfluence and then growth arrested for 48 hours in DMEM containing 0.1\% FBS. Cells were pretreated with $\mathrm{m} 7 \mathrm{E} 3, \mathrm{c7E} 3$ or eptifibatide for 1 hour, and then stimulated for $10 \mathrm{~min}$ at $37^{\circ} \mathrm{C}$ with $1 \mathrm{uM}$ Insulin (Sigma). Cells were washed twice with ice-cold PBS containing $0.5 \mathrm{mM}$ vanadate and then lysed with icecold cell lysis buffer plus protease inhibitor cocktail (Roche Diagnostics $\mathrm{GmbH}$ ) on ice for 10 minutes. JNK1 kinase activity was measured using a GST-c-JUN pulldown assay as previously described[9].

\section{Statistical analysis}

Results are expressed as mean \pm standard deviation unless otherwise stated. One way analysis of variance followed by the Dunnett's multiple range test was used to analyze data. A p value of less than or equal to 0.05 was considered statistically significant. Triplicate wells were analyzed for each experiment and each experiment was performed independently a minimum of three times.

\section{Results \\ HASMC express $\alpha_{v} \beta_{3}$ integrins}

Flow cytometry was performed utilizing LM609, a monoclonal antibody that binds $\alpha_{\mathrm{v}} \beta_{3}$ integrins with high specificity[11], m7E3, a monoclonal anti- $\beta_{3}$ integrin antibody from which abciximab is derived, and 10E5, a monoclonal antibody that binds $\alpha_{\mathrm{IIb}} \beta_{3}$ but not $\alpha_{\mathrm{v}} \beta_{3}$. Results demonstrated that HASMC express $\alpha_{\mathrm{v}} \beta_{3}$ and that $\beta_{3}$ subunits form heterodimers primarily, if not solely, with $\alpha_{\mathrm{v}}$ subunits in HASMC (figures $1 \mathrm{~A}$ and $1 \mathrm{~B}$; binding to HASMC in arbitrary binding units: no antibody $1.0 \pm 0.2,10 \mathrm{E} 51.4 \pm 0.2, \mathrm{~m} 7 \mathrm{E} 33.1 \pm 0.3$ and LM609 $3.2 \pm 0.5 ; \mathrm{p}<0.05$ for m7E3 vs. $10 \mathrm{E} 5$ and LM609 vs. 10E5).

Apoptosis, as determined by Annexin V binding to the cell surface, was present in less than $10 \%$ of HASMC maintained in quiescent media for 120 hours (figure 1C) and did not increase with insulin treatment. Treatment with various integrin inhibitors for 48 hours after HASMC had been maintained in quiescent media for 72 hours did not increase the number of apoptotic SMC, either with or without insulin. At the concentrations used in these studies, neither m7E3, c7E3 nor eptifibatide had any effect on cell adhesion (figure 1D). These results are consistent with prior studies showing that attachment of HASMC to noncoated tissue culture plates is primarily mediated by various $\beta_{1}$-integrins[12]. 
A.

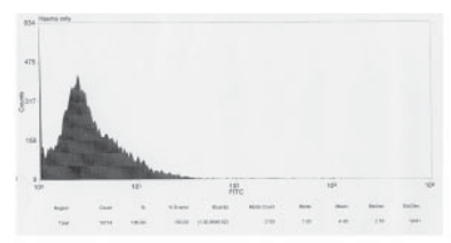

Control - no antibody

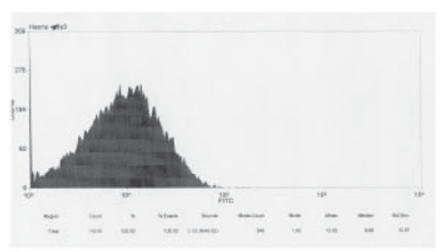

$7 \mathrm{E3}$

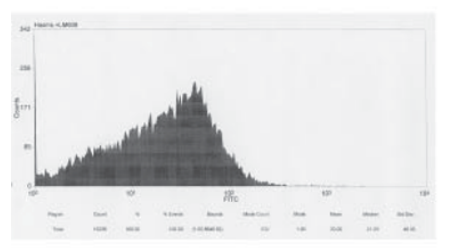

LM609
B.

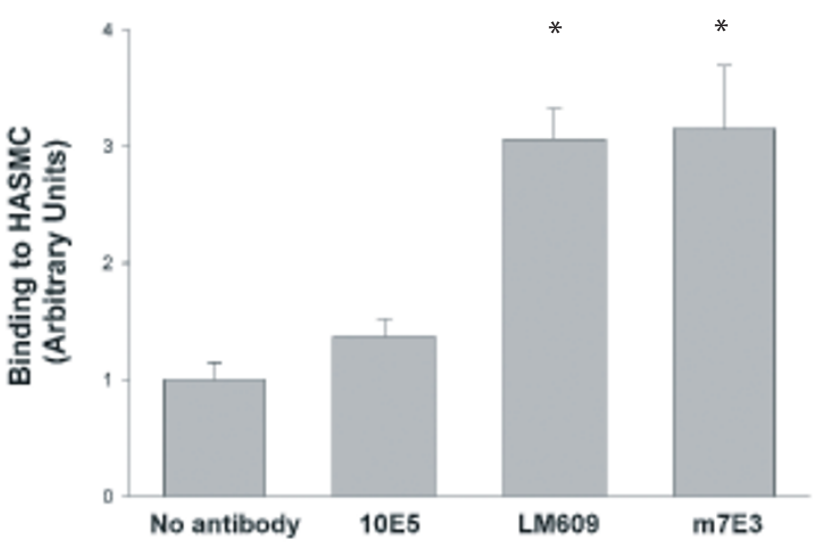

C.

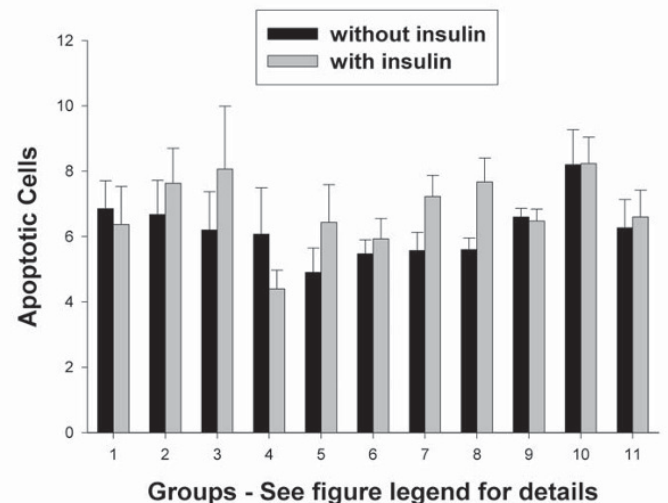

D.

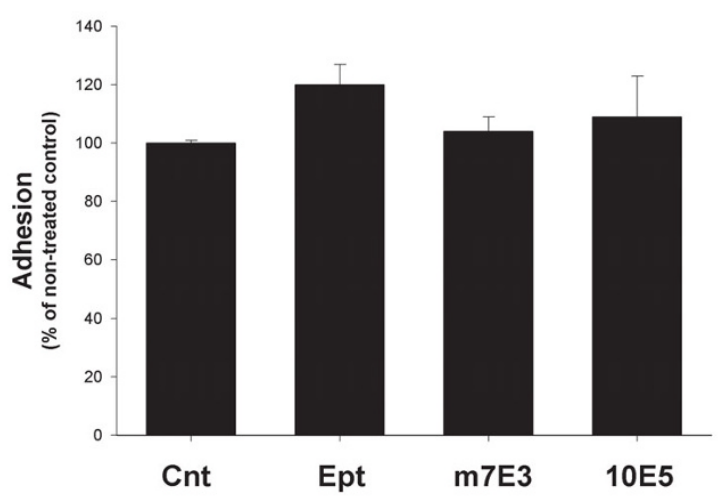

Figure I

Expression of $\alpha_{v} \beta_{3}$ integrins by HASMC and effect of $\alpha_{v} \beta_{3}$ antagonists on cell adhesion and apoptosis. Results of a representative FACS experiment (A) and data from 5 independent experiments $(B)$ are shown $(*=p<0.05$ vs no antibody or vs IOE5). HASMC growth-arrested for 72 hours were treated with insulin $(\mathrm{I} \mu \mathrm{mol} / \mathrm{L})$ or vehicle \pm integrin inhibitors. 48 hours later (I20 hours after the addition of quiescent media), Annexin $V$ staining was determined (C). The groups are as follows: I no inhibitor, 2 - I0E5, 3 - m7E3, 4 - c7E3, 5 - LM609, 6 - eptifibatide, 7 - tirofiban, 8 - cRGD, 9 - RGD, 10 - RGE and II RAD. HASMC in suspension were incubated with eptifibatide, RGE peptides, m7E3 or I0E5 and then added to non-coated tissue culture plates. Cell adhesion was determined as described in Methods (D). Concentrations of inhibitors were as follows: m7E3, c7E3, LM609 and I0E5 (30 $\mu \mathrm{g} / \mathrm{ml})$; eptifibatide, GRGDS, GRDGS or GRADSP peptides ( $10 \mu \mathrm{mol} / \mathrm{L})$ and tirofiban (30 $\mu \mathrm{mol} / \mathrm{L})$. 


\section{$\alpha_{v} \beta_{3}$ antagonists inhibit insulin induced proliferation of HASMC}

Insulin elicited a dose-dependent proliferative response of HASMC that were growth arrested in $0.5 \%$ FBS for 72 hours prior to treatment. The proliferative response, as determined by cell number assays three days after treatment, to insulin at a concentration of $1 \mu \mathrm{mol} / \mathrm{L}(107 \pm$ $18 \%$ increase in cell number; $n=7$; range $25-168 \%$ ) was similar to that elicited by platelet-derived growth factor$\mathrm{BB}$ (PDGF-BB) (figure 2A; $85 \pm 14 \% ; \mathrm{n}=3$; $\mathrm{p}=\mathrm{ns}$ compared to insulin).

Treatment of HASMC with m7E3 $(30 \mu \mathrm{g} / \mathrm{ml})$ for one hour prior to the addition of insulin inhibited proliferative responses by approximately $70 \%$ (figure $2 \mathrm{~B}$ ). The inhibitory effects of $60 \mu \mathrm{g} / \mathrm{ml}$ or $100 \mu \mathrm{g} / \mathrm{ml}$ of m7E3 on insulininduced proliferation were the same as that observed with $30 \mu \mathrm{g} / \mathrm{ml}$ ( $\mathrm{p}=\mathrm{ns}$ for differences between various concentrations).

Pretreatment with LM609 at the same dose also inhibited proliferative responses to insulin but to a lesser extent. m7E3 had a more profound inhibitory effect than LM609 even though the affinity of m7E3 for HASMC $\left(\mathrm{K}_{\mathrm{D}}=3.8 \pm\right.$ $0.4 \mathrm{nmol} / \mathrm{L}$ ) is an order of magnitude less than that of LM609 for HASMC $\left(K_{D}=0.18 \pm 0.01 \mathrm{nmol} / \mathrm{L}\right)[5]$. Pretreatment with 10E5 had no effect.

c7E3 Fab (abciximab) is a chimeric antigen binding fragment derived from m7E3 which was designed to minimize antigenicity when given to humans. It contains the heavy and light chain variable regions from the murine antibody attached to the constant regions of human IgG1 and kappa chains, respectively. Pretreatment with c7E3 $(30 \mu \mathrm{g} / \mathrm{ml})$ inhibited $56 \%$ of the proliferative response to insulin. There was no additional inhibitory effect observed with higher concentrations of c7E3.

Two other $\beta_{3}$ integrin antagonists, eptifibatide and tirofiban, are used in clinical medicine in addition to abciximab. Pretreatment of HASMC with eptifibatide at a concentration of $5 \mu \mathrm{mol} / \mathrm{L}$ blocked $83 \%$ of insulininduced proliferation (figure 2C). At higher concentrations, eptifibatide completely abolished insulin-induced proliferation. In contrast, tirofiban, a nonpeptide derivative of tyrosine that does not bind $\alpha_{v} \beta_{3}$ integrins, had no effect.

Cyclic RGD peptides (GPenGRGDSPCA; cRGD) are specific $\alpha_{v}$ antagonists that recognize both $\alpha_{v} \beta_{3}$ and $\alpha_{v} \beta_{5}[13]$. cRGD block $\alpha_{v} \beta_{3}$-mediated migration and proliferation of rat aortic SMC, $\alpha_{v} \beta_{5}$-mediated adhesion of RASMC to vitronectin and neointimal formation following rat carotid artery balloon injury $[9,13,14]$. At a concentration of 10 $\mu \mathrm{mol} / \mathrm{L}$, cRGD completely inhibited insulin-induced pro- liferation (figure 2C). RDG and RAD peptides, used as controls, blocked $39 \%$ and $31 \%$ of the proliferative response to insulin, respectively ( $\mathrm{p}<0.05$ compared to insulin alone).

\section{Inhibitory effects of m7E3 are mediated by $\alpha_{v} \beta_{3}$ antagonism}

Further confirmation that the inhibitory effects of m7E3 on responses to insulin were mediated via $\alpha_{v} \beta_{3}$ antagonism was provided by studies in human embryonic kidney (HEK) cells that express $\alpha_{v}$ subunits but not $\beta_{3}$ subunits. These cells were transfected with pcDNA-1neo constructs[10] encoding $\beta_{3}$ integrin subunits and stable expression of $\beta_{3}$ integrins and formation of $\alpha_{v} \beta_{3}$ complexes was confirmed by immunoprecipitation with LM609 followed by Western analysis[5]. HEK cells that expressed $\beta_{3}$ subunits proliferated at a rate that was $46 \%$ greater than mock-transfected HEK cells when grown in $5 \%$ serum on standard tissue culture plates (figure $3 \mathrm{~A}$ ). Interestingly, $\beta_{3}$-HEK cells showed a significant proliferative response to $0.5 \%$ serum in contrast to mock-transfected HEK cells. Insulin was a potent mitogen for both $\beta_{3}$-transfected and mock-transfected HEK cells; in both cell types proliferative responses to insulin were greater than to $5 \%$ serum. But, whereas m7E3 had no effect on insulin-induced proliferation in mock-transfected HEK cells, m7E3 inhibited approximately $60 \%$ of insulininduced proliferation in $\beta_{3}$-transfected HEK cells (figure $3 \mathrm{~B})$.

\section{$\alpha_{v} \beta_{3}$ antagonists inhibit insulin-induced JNK, but not insulin-induced $E R K$, activity}

Exposure to insulin results in the stimulation of multiple signaling pathways $[15,16]$ but mitogen activated protein kinases (MAPK) are generally thought to regulate biological actions related to growth and proliferation[17]. Since integrins mediate activation of extracellular signal-regulated kinase (ERK)[18] and c-Jun $\mathrm{NH}_{2}$-terminal kinase-1 (JNK1; also known as stress-activated protein kinase-1)[9] we next sought to determine if $\alpha_{v} \beta_{3}$ antagonists influenced insulin-induced ERK or JNK1 activity. Treatment with insulin elicited a mild increase in ERK $1 / 2$ phosphorylation but pretreatment with eptifibatide, m7E3 or c7E3, at concentrations that reduced proliferation, had no effect on this response (figure 4A). In particular, neither m7E3 at a concentration that reduced insulin-induced proliferation by approximately $80 \%$, c7E3 at a concentration that reduced insulin-induced proliferation by approximately 55\% nor eptifibatide at a concentration that inhibited insulin-induced proliferation by $83 \%$ had any discernible effect on levels of tyrosine phosphorylated ERK.

Previous studies have shown JNK1 is phosphorylated in response to treatment of HASMC with insulin[19]. To 
A

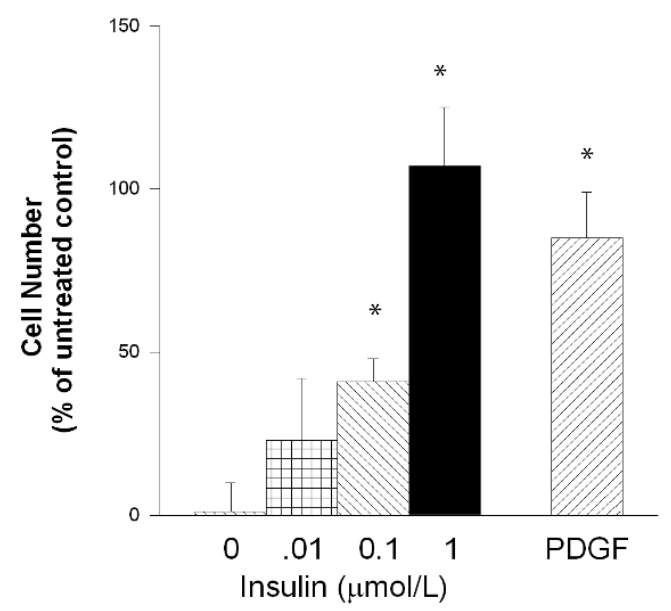

B

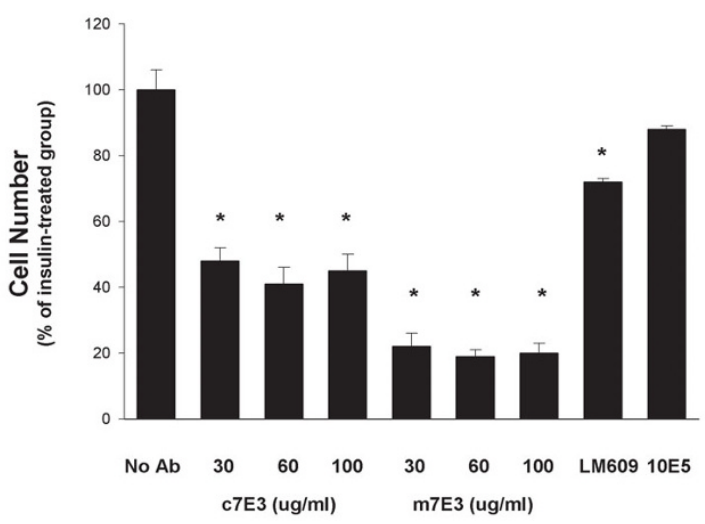

\section{Figure 2}

Effect of $\alpha_{v} \beta_{3}$ antagonists on insulin-induced proliferation. Growth arrested HASMC were treated with insulin (various concentrations), PDGF-BB (I.4 nmol/L) or vehicle and cell number was determined three days later (A). In the experiments represented in panels $B$ and C, HASMC were treated with antibodies or peptides as indicated for one hour prior to addition of insulin $(\mathrm{I} \mu \mathrm{mol} / \mathrm{L})$. Concentrations of antibodies and peptides were the same as in figure I unless indicated. $\left[^{*}=p<0.05\right.$ vs control $(A) ; *=p<0.05$ vs I0E5 $(B) ; *=p<0.05$ vs tirofiban $(C)]$ 

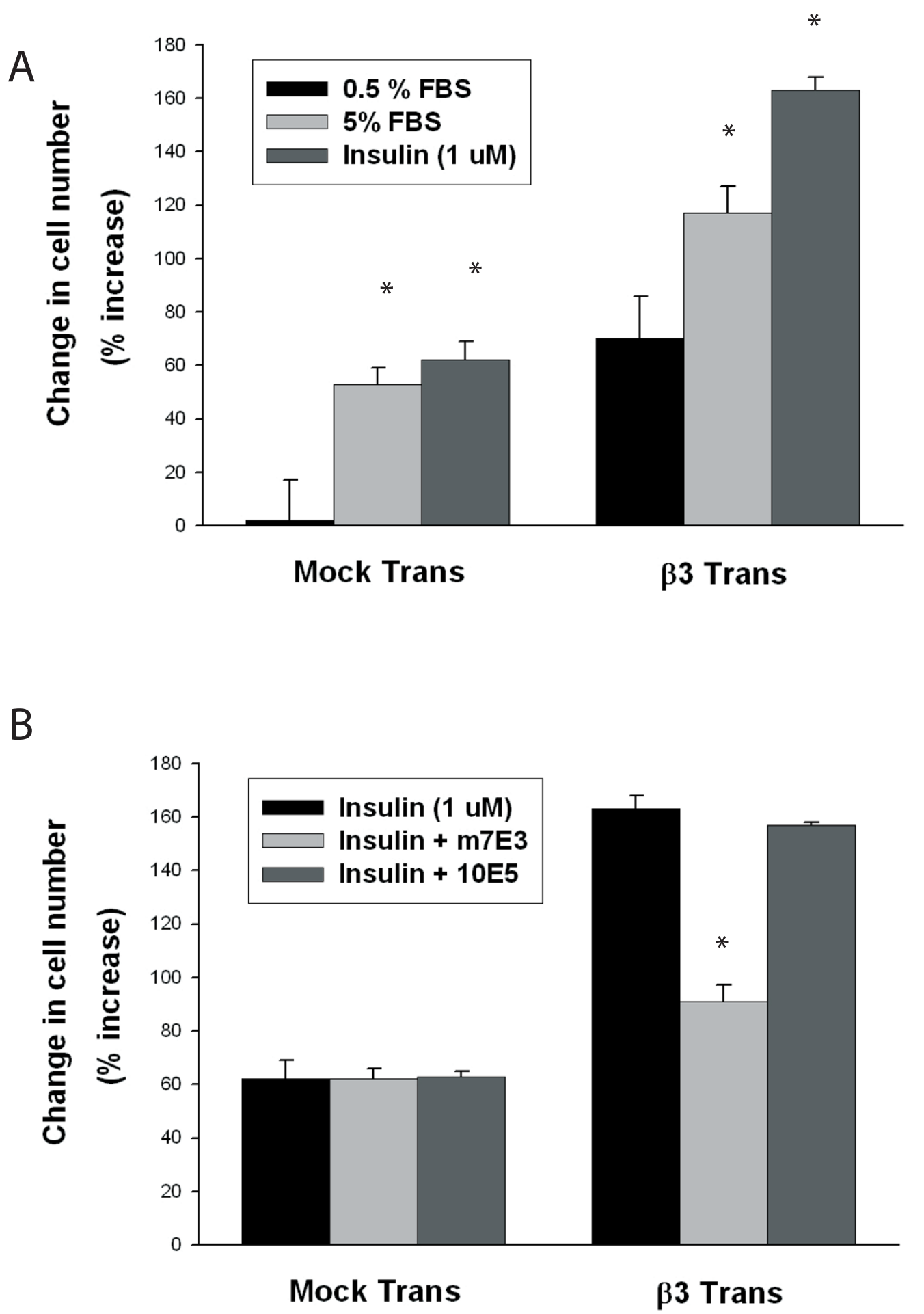

Figure 3

Effects of $\mathrm{m7E} 3$ on proliferative responses of HEK cells. $\beta_{3}$ integrin-deficient HEK cells were transfected with an empty vector or pcDNA-I neo constructs encoding full-length $\beta_{3}$ integrin subunits. The cells were grown in serum-containing media $(0.5 \%$ or $5 \%)$ or insulin $(I \mu \mathrm{mol} / \mathrm{L})$ for five days $(A)$. In panel $B$, insulin $(I \mu \mathrm{mol} / \mathrm{L})$ was added $\pm \mathrm{m7E} 3$ or $\mathrm{IOE} 5(20 \mu \mathrm{g} / \mathrm{ml})$. Cell number assays were performed 5 days later. $[*-p<0.05$ vs $0.5 \%$ FBS in $A$ and $*-p<0.05$ vs insulin or insulin $+10 E 5$ in B]. 
A.

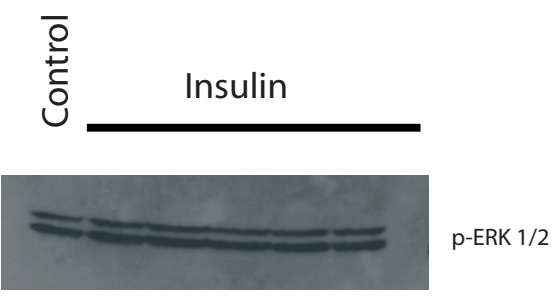

m7E3 (ug/ml)

$\begin{array}{llllll}0 & 0 & 20 & 50 & 100 & 200\end{array}$

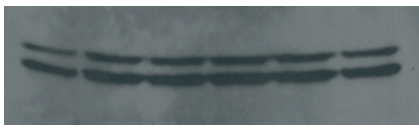

p-ERK $1 / 2$

c7E3 (ug/ml)

$\begin{array}{llllll}0 & 0 & 20 & 50 & 100 & 200\end{array}$

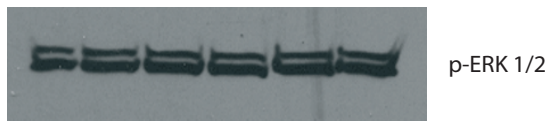

Eptifibatide (umol/L)

$\begin{array}{llllll}0 & 0 & 20 & 50 & 100 & 200\end{array}$

B.
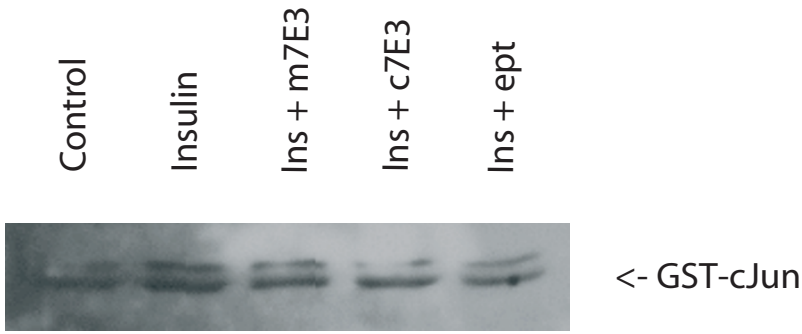

C.

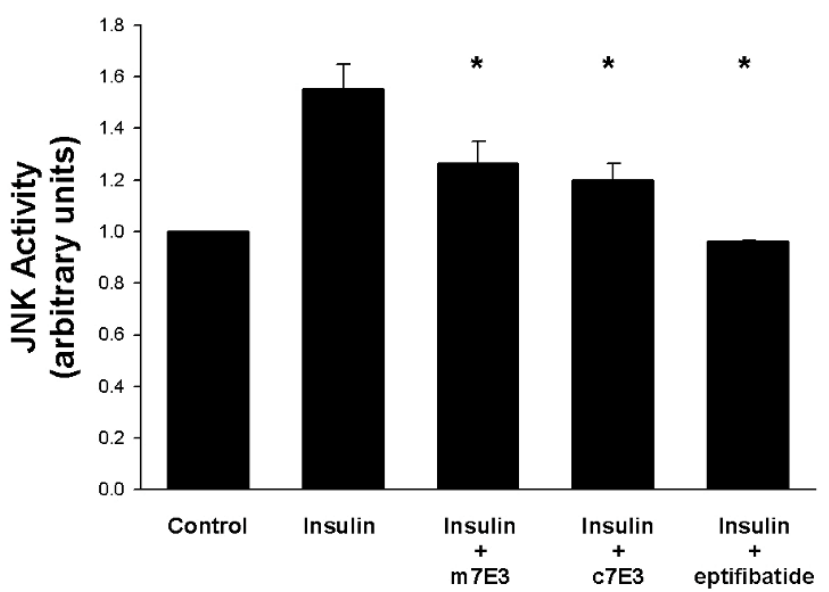

Figure 4

Effect of c7E3, m7E3 and eptifibatide on insulin-induced ERK and JNK activation. Growth arrested HASMC were treated with m7E3, c7E3 or eptifibatide (indicated concentrations in A, both antibodies were used at $30 \mu \mathrm{g} / \mathrm{ml}$ and eptifibatide at $10 \mu \mathrm{mol} / \mathrm{L}$ in $B$ and $C)$ as indicated for one hour. Insulin $(I \mu \mathrm{mol} / \mathrm{L})$ or vehicle was added and ten minutes later ERK and JNKI activity were determined as described in Methods. 
determine the effect of $\alpha_{v} \beta_{3}$ antagonists on insulininduced activation of JNK1, we utilized an in vitro immunocomplex kinase assay with GST-c-jun as the substrate. Others have previously shown using the same experimental system that $\alpha$-thrombin stimulation of JNK- 1 activity is associated with subsequent increases in c-jun expression, AP-1-DNA binding activity and AP-1 transactivation activity[20]. Pretreatment with m7E3, c7E3 or eptifibatide for one hour reduced insulin-induced JNK1 activity measured 10 minutes after treatment of HASMC (figures $4 \mathrm{~B}$ and 4C).

\section{Insulin stimulates the formation of focal adhesions and this effect is partially inhibited by $\alpha_{v} \beta_{3}$ antagonists}

There is evidence that efficient activation of JNK1 in SMC occurs at focal adhesions, sites where integrins, cytoskeletal proteins and signaling proteins converge[21]. Focal adhesions form at the ends of F-actin stress fibers and transmit tension between the contractile apparatus and extracellular matrix. Previously we found that $\alpha_{\mathrm{v}} \beta_{3}$ antagonists inhibited JNK1 activation and focal adhesion formation in SMC in response to treatment with $\alpha$ thrombin[9]. Treatment with insulin resulted in a $66 \%$ increase in focal adhesions (as determined by vinculin staining) within 5 minutes (figure 5). In a growth arrested, quiescent state there were $31 \pm 3$ focal adhesions per HASMC and this number increased to $49 \pm 2$ following five minute exposure to insulin. Pretreatment with m7E3 completely inhibited insulin-induced increases in focal adhesions. Insulin-induced increases in focal adhesions were inhibited by $74 \%$ and $73 \%$ by pretreatment with c7E3 or eptifibatide, respectively.

\section{Discussion}

Antagonism of $\alpha_{v} \beta_{3}$ integrins markedly inhibits proliferative responses of HASMC to insulin. This conclusion is based on our findings that insulin-induced proliferation was inhibited by anti- $\beta_{3}$ integrin monoclonal antibody (m7E3), chimeric antigen binding fragment of 7E3 (c7E3), anti- $\alpha_{v} \beta_{3}$ monoclonal antibody (LM609), anti- $\beta_{3}$ peptides (eptifibatide) and anti- $\alpha_{\mathrm{v}}$ peptides (cRGD). These studies add to the wealth of data that $\alpha_{v} \beta_{3}$ antagonists have profound effects on SMC proliferation and migration, two mechanisms that play central roles in vascular pathology. In various studies, $\alpha_{v} \beta_{3}$ antagonists have been shown to inhibit proliferative responses of SMC to insulin, thrombospondin, thrombin, IGF-1, osteopontin, Del1 and transforming growth factor- $\beta$ and to inhibit migratory responses of SMC to insulin-like growth factor1 - (IGF-1), PDGF, vitronectin, thrombospondin and osteopontin (reviewed in[22]). In animal models, $\alpha_{v} \beta_{3}$ antagonists have been shown to reduce SMC migration, SMC proliferation and neointima formation following vascular injury[14,23].
In this study, insulin stimulated a proliferative response in quiescent HASMC maintained in $0.5 \%$ FBS that was similar in magnitude to that observed with PDGF-BB. These results are consistent with previous studies which showed that insulin can stimulate proliferation of cultured SMC and also enhance proliferative responses to other mitogens[24-26]. Insulin has also been found to stimulate neointimal formation and proliferation of organ cultures of saphenous veins and internal mammary arteries[27]. Saphenous vein responses to insulin were similar in magnitude to those observed with PDGF-BB whereas insulin was a less efficacious mitogen than PDGF-BB in internal mammary cultures. In contrast to these studies, Obata et al.[28] found that low concentrations of insulin stimulated insulin receptor substrate-1 phosphorylation and amino acid uptake but not thymidine incorporation into DNA in rat aortic SMC. The concentrations of insulin used by Obata et al $(1-10 \mathrm{nmol} / \mathrm{L})$ were approximately 100 fold lower than used in the present studies.

We found that focal adhesions as delineated by anti-vinculin staining formed rapidly following treatment of quiescent HASMC with insulin and that $\alpha_{\mathrm{v}} \beta_{3}$ antagonists partially inhibited this response. Vinculin is one of the first actin binding proteins recruited into focal adhesions [29]. It is widely used as a marker of 'classic' focal adhesions, which are usually located at the cell periphery, are highly tyrosine phosphorylated, and contain $\alpha_{\mathrm{v}} \beta_{3}$ integrins. Vinculin is also found in focal complexes, which are short-lived structures that mature into focal adhesions.

Recent studies have highlighted the existence of two major signaling pathways that are initiated by insulin binding to the insulin receptor and which mediate insulin action $[15,16]$. One pathway, which involves IRS proteins and phosphatidylinositol 3-kinase, appears to be responsible for most, if not all, of the metabolic aspects of insulin action. The second signaling pathway, involving Ras and mitogen activated protein kinase (MAPK), is responsible for proliferative responses to insulin. Doronzo et al reported that insulin increased ERK 1/2 and JNK1 phosphorylation in HASMC in a time dependent manner beginning within 5 minutes of treatment[19]. In the present studies, we found that antagonism of $\alpha_{\mathrm{v}} \beta_{3}$ inhibited insulin-induced activation of JNK1, but not ERK 1/2, in HASMC. JNK1 is a member of the mitogen activated protein kinase superfamily that is activated by dual phosphorylation at a Thr-Pro-Tyr motif and once activated, functions to phosphorylate c-jun at amino terminal serine regulatory sites which increases activity of the transcription factor AP-1. A clear link between JNK1 activation and proliferation in insulin-treated HASMC has not been established although JNK antagonists has been reported 


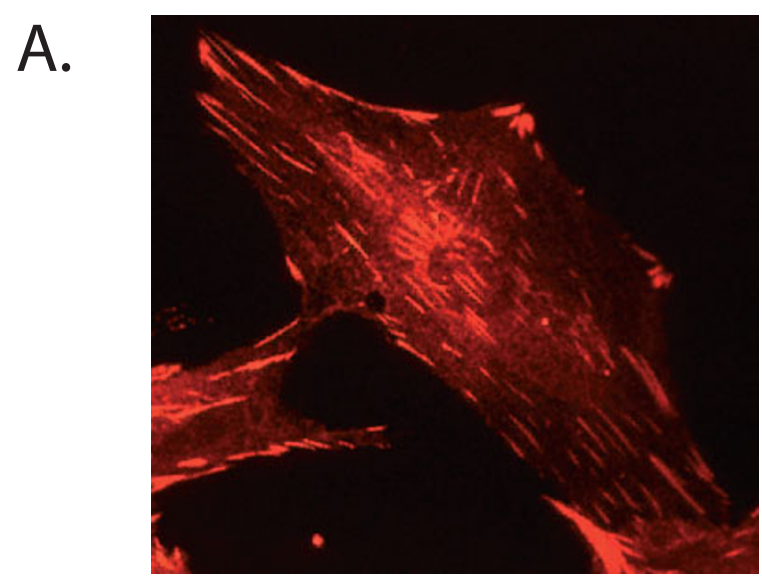

\section{Control}

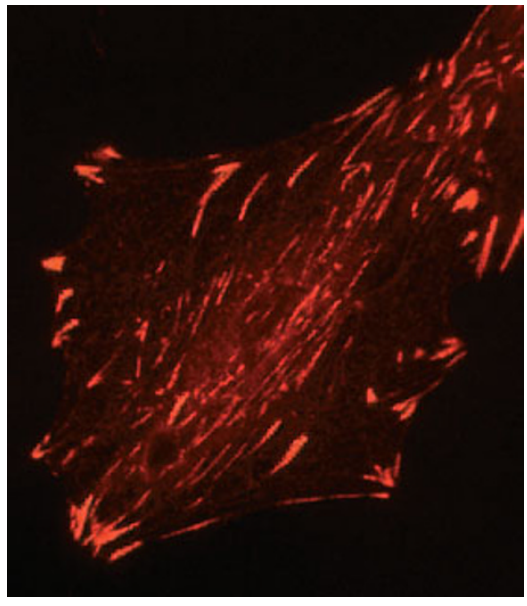

\section{Insulin}

B.

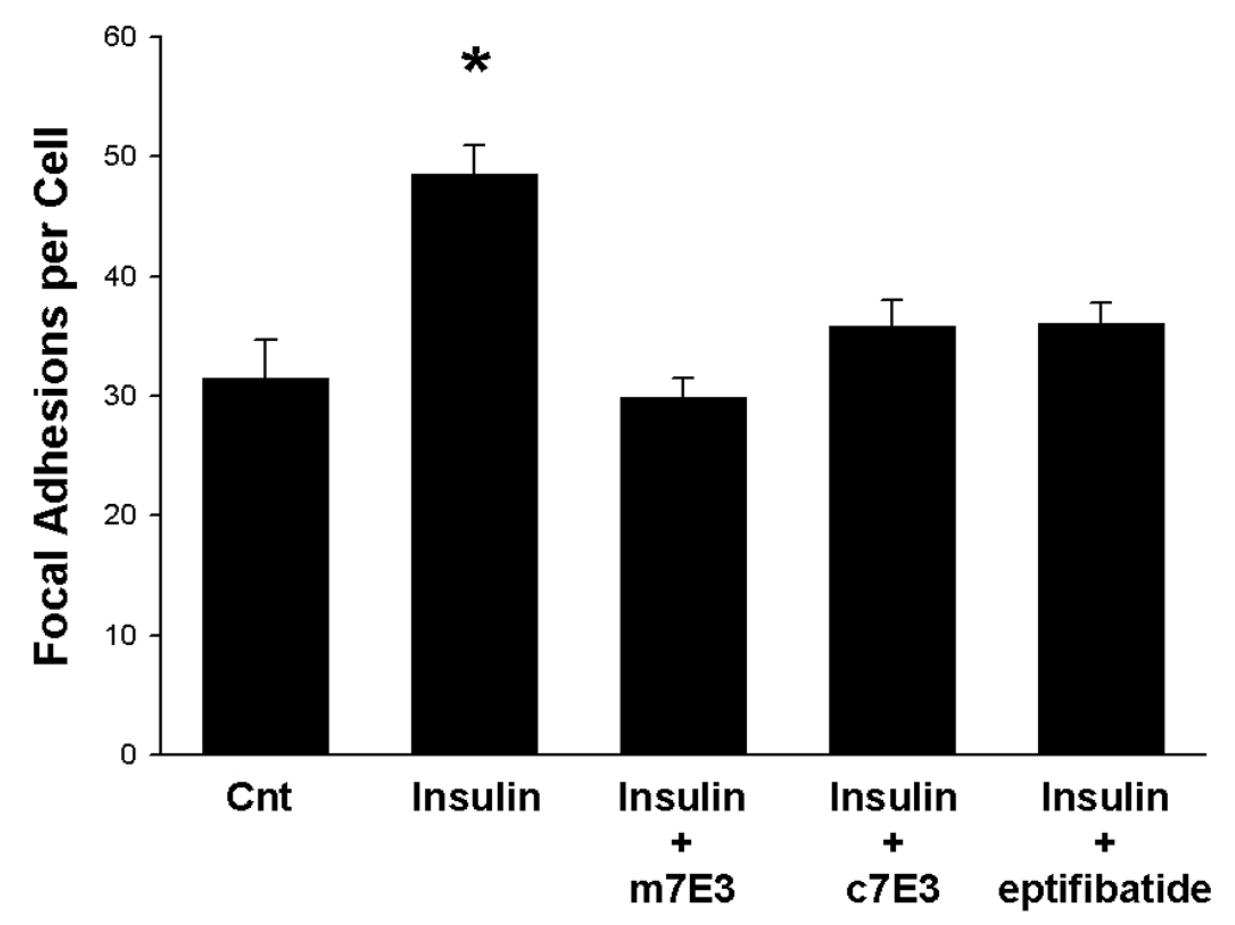

Figure 5

Effect of c7E3, m7E3 and eptifibatide on insulin-induced focal adhesion formation. Growth arrested HASMC were treated with m7E3, c7E3 (both antibodies were used at $30 \mu \mathrm{g} / \mathrm{ml}$ ) or eptifibatide $(10 \mu \mathrm{mol} / \mathrm{L})$ as indicated for one hour. Insulin ( $\mathrm{I} \mu \mathrm{mol} / \mathrm{L})$ or vehicle were added and five minutes later, focal adhesions in 50 representative cells were determined using vinculin staining. Data represent the mean \pm SEM from four independent experiments. ${ }^{*}-p=0.05$ relative to insulin]. 
to inhibit proliferation of cultured SMC in other systems[30,31]. In studies utilizing the rat carotid balloon injury model, transfection of a dominant negative JNK prior to injury prevented neointimal formation and markedly suppressed SMC proliferation in both the intima and the media after rat carotid artery injury[32].

The inhibitory effect of $\alpha_{v} \beta_{3}$ antagonists on JNK1 activation occurs in response to a variety of stimuli. In addition to inhibiting JNK1 activation in response to insulin, $\alpha_{v} \beta_{3}$ antagonists inhibit $\alpha$-thrombin-induced[9] and TFBinduced[33] JNK1 activation in SMC. Several potential mechanisms that might explain these results are suggested by recent studies. Activation of the small G protein Rho is mediated by integrin engagement [34] and recently Ohtsu et al reported that activation of Rho, and its effector Rhokinase/ROCK was required for angiotensin II-induced JNK activation in SMC. Alternatively, studies in myocytes[35] and HEK cells[21,36] have implicated the formation of protein complexes involving focal adhesion kinase in activation of JNK.

$\alpha_{v} \beta_{3}$ antagonists inhibited insulin-induced proliferation without blocking ERK 1/2 phosphorylation. The biochemical steps involved in signal transduction through the ERK pathway are well established but less is known about how these signals are implemented into specific biological responses, and in particular the role of intracellular localization of members of this pathway. Following activation, ERK localizes to different subcellular compartments, including focal adhesions, and phosphorylates specific proteins leading to cellular responses. The specificity of the biological response is likely to be at least partially controlled by the localization of signaling, which enables ERK activity to be directed towards specific targets. Integrin engagement is necessary for active ERK localization to focal adhesions suggesting that a potential mechanism whereby integrin antagonism could inhibit growth but not ERK phosphorylation is via interrupting ERK targeting[37].

Tirofiban had no effect on insulin-induced proliferation, consistent with prior studies showing that tirofiban does not antagonize $\alpha_{v} \beta_{3}[5]$. The different affinities of eptifibatide and tirofiban for $\alpha_{v} \beta_{3}$ are not surprising given that eptifibatide is a synthetic, cyclic peptide with a Lys-GlyAsp (KGD) sequence whereas tirofiban is a nonpeptide derivative of tyrosine. Tirofiban was used at a concentration of $30 \mu \mathrm{mol} / \mathrm{L}$ and eptifibatide was used at various concentrations between 5 and $100 \mu \mathrm{mol} / \mathrm{L}$ in our studies. This concentration of tirofiban is approximately 700 fold greater than peak plasma concentration observed in patients $(40 \mathrm{ng} / \mathrm{ml})$ receiving a continuous infusion[38]. There is wide inter-individual variation in plasma levels however, and it is also unknown whether tirofiban con- centrations are higher within the vessel wall than in plasma.

Intimal thickening due to abnormal proliferation of vascular smooth muscle cells is the major cause of revascularization failures in diabetics. Since $\alpha_{v} \beta_{3}$ integrin expression is upregulated in atherosclerotic lesions and at sites of balloon angioplasty, these results suggest that one way to potentially regulate insulin effects on SMC at sites of vascular healing is via antagonism of $\alpha_{v} \beta_{3}$.

\section{Competing interests}

The authors declare that they have no competing interests.

\section{Authors' contributions}

AP performed the flow cytometry, proliferation and binding assays. He also assisted in interpreting the data and writing the manuscript. RZ performed the focal adhesion assays and immunoflouresence studies. JH performed the western blots and JNK assays. GAS conceived of the study, participated in the design, coordinated the interpretation of the data and drafted the manuscript. All authors read and approved the final manuscript.

\section{Acknowledgements}

This work was supported by grant ROIHL702 I3-I from the National Heart, Lung and Blood Institute

\section{References}

I. Luscher TF, Creager MA, Beckman JA, Cosentino F: Diabetes and vascular disease: pathophysiology, clinical consequences, and medical therapy: Part II. Circulation 2003, I 08: I655-I66I.

2. Bhatt DL, Marso SP, Lincoff AM, Wolski KE, Ellis SG, Topol EJ: Abciximab reduces mortality in diabetics following percutaneous coronary intervention. J Am Coll Cardiol 2000, 35:922-928.

3. Labinaz M, Madan M, O'Shea JC, Kilaru R, Pieper K, McGuire DK, Saucedo JF, Talley JD, Lui H, Kitt MM, Califf RM, Tcheng JE, for the ESPRIT Investigators: Comparison of one-year outcomes following coronary artery stenting in diabetic versus nondiabetic patients. Am J Cardiol 2002, 90:585-590.

4. Stouffer GA, Hu Z, Sajid M, Li H, Jin G, Nakada MT, Hanson SR, Runge $M S: \beta_{3}$ integrins are upregulated following vascular injury and mediate proliferation of cultured smooth muscle cells. Circulation 1998, 97:907-915.

5. Lele M, Sajid M, Wajih N, Stouffer GA: Eptifibatide and 7E3, but not tirofiban, inhibit $\alpha_{y} \beta_{3}$ integrin-mediated binding of smooth muscle cells to thrombospondin and prothrombin. Circulation 2001, I 04:582-587.

6. Vuori K, Ruoslahti E: Association of insulin receptor substrateI with integrins. Science 1994, 266: I576-1578.

7. Schneller $M$, Vuori K, Ruoslahti $E: \alpha_{v} \beta_{3}$ integrin associates with activated insulin and PDGF $\beta$ receptors and potentiates the biological activity of PDGF. EMBO Journal 1997, I6:5600-5607.

8. Lopez-Alemany R, Redondo JM, Nagamine $Y$, Munoz-Canoves P: Plasminogen activator inhibitor type- $I$ inhibits insulin signaling by competing with $\alpha_{v} \beta_{3}$ integrin for vitronectin binding. Eur J Biochem 2003, 270:814-82I.

9. Sajid $M$, Zhao R, Pathak A, Smyth SS, Stouffer GA: $\alpha_{v} \beta_{3}$ integrin antagonists inhibit thrombin-induced proliferation and focal adhesion formation in smooth muscle cells. Am J Physiol Cell Physiol 2003, 285:CI330-CI338.

10. Filardo EJ, Brooks PC, Deming SL, Damsky C, Cheresh DA: Requirement of the NPXY motif in the integrin $\beta_{3}$ subunit cytoplasmic tail for melanoma cell migration in vitro and in vivo. $J$ Cell Biol 1995, I 30:44I-450. 
11. Cheresh DA: Human endothelial cells synthesize and express an Arg-Gly-Asp-directed adhesion receptor involved in attachment to fibrinogen and von Willebrand factor. Proc Natl Acad Sci USA 1987, 84:647I-6475.

12. Clyman RI, Mauray F, Kramer RH: $\beta$ I and $\beta 3$ integrins have different roles in the adhesion and migration of vascular smooth muscle cells on extracellular matrix. Exp Cell Res 1992 200:272-284.

13. Bilato C, Curto KA, Monticone RE, Pauly RR, White AJ, Crow MT: The inhibition of vascular smooth muscle cell migration by peptide and antibody antagonists of the $\alpha_{v} \beta_{3}$ integrin complex is reversed by activated calcium/calmodulin- dependent protein kinase II. J Clin Invest 1997, 100:693-704.

14. Slepian MJ, Massia SP, Dehdashti B, Fritz A, Whitesell L: $\beta 3$-integrins rather than $\beta I$-integrins dominate integrin-matrix interactions involved in postinjury smooth muscle cell migration. Circulation 1998, 97:1818-1827.

15. Cheatham B, Kahn CR: Insulin action and the insulin signaling network. Endocr Rev 1995, 16:1 17-142.

16. Wang CC, Gurevich I, Draznin B: Insulin affects vascular smooth muscle cell phenotype and migration via distinct signaling pathways. Diabetes 2003, 52:2562-2569.

17. Muniyappa R, Montagnani M, Koh KK, Quon MJ: Cardiovascular actions of insulin. Endocr Rev 2007, 28:463-491.

18. Aplin AE, Juliano RL: Integrin and cytoskeletal regulation of growth factor signaling to the MAP kinase pathway. J Cell Sci 1999, I I 2:695-706.

19. Doronzo G, Russo I, Mattiello L, Riganti C, Anfossi G, Trovati M: Insulin activates hypoxia-inducible factor-Ialpha in human and rat vascular smooth muscle cells via phosphatidylinositol-3 kinase and mitogen-activated protein kinase pathways: impairment in insulin resistance owing to defects in insulin signalling. Diabetologia 2006, 49:1049-1063.

20. Rao GN, Katki KA, Madamanchi NR, Wu Y, Birrer MJ: JunB forms the majority of the AP-I complex and is a target for redox regulation by receptor tyrosine kinase and $G$ protein-coupled receptor agonists in smooth muscle cells. I Biol Chem 1999, 274:6003-60I0.

21. Oktay M, Wary KK, Dans M, Birge RB, Giancotti FG: Integrinmediated activation of focal adhesion kinase is required for signaling to Jun NH2-terminal kinase and progression through the GI phase of the cell cycle. J Cell Biol 1999, |45: I 46I-|469.

22. Sajid $M$, Stouffer GA: The role of $\alpha_{v} \beta_{3}$ integrins in vascular healing. Thromb Haemost 2002, 87:187-193.

23. Bendeck MP, Irvin C, Reidy M, Smith L, Mulholland D, Horton M, Giachelli CM: Smooth muscle cell matrix metalloproteinase production is stimulated via alpha(v)beta(3) integrin. Arterioscler Thromb Vasc Biol 2000, 20:1467-1472.

24. Agazie YM, Bagot JC, Trickey E, Halenda SP, Wilden PA: Molecular mechanisms of ATP and insulin synergistic stimulation of coronary artery smooth muscle growth. Am J Physiol Heart Circ Physiol 200I, 280: H795-H80I.

25. Forsyth EA, Aly HM, Najiar SF, Neville RF, Sidawy AN: Transforming growth factor beta $I$ inhibits the proliferative effect of insulin on human infragenicular vascular smooth muscle cells. J Vasc Surg 1997, 25:432-436.

26. Goetze S, Kim S, Xi XP, Graf K, Yang DC, Fleck E, Meehan WP, Hsueh WA, Law RE: Troglitazone inhibits mitogenic signaling by insulin in vascular smooth muscle cells. J Cardiovasc Pharmacol 2000, 35:749-757.

27. Huang B, Dreyer T, Heidt M, Yu JC, Philipp M, Hehrlein FW, Katz N, Al Fakhri N: Insulin and local growth factor PDGF induce intimal hyperplasia in bypass graft culture models of saphenous vein and internal mammary artery. Eur J Cardiothorac Surg 2002, 21:1002-1008

28. Obata T, Kashiwagi A, Maegawa $H$, Nishio $Y$, Ugi S, Hidaka $H$, Kikkawa R: Insulin signaling and its regulation of system $A$ amino acid uptake in cultured rat vascular smooth muscle cells. Circ Res 1996, 79: I 167-II76.

29. Zaidel-Bar R, Ballestrem C, Kam Z, Geiger B: Early molecular events in the assembly of matrix adhesions at the leading edge of migrating cells. / Cell Sci 2003, I | 6:4605-46 I3.

30. Kavurma MM, Khachigian LM: ERK, JNK, and p38 MAP kinases differentially regulate proliferation and migration of pheno- typically distinct smooth muscle cell subtypes. J Cell Biochem 2003, 89:289-300.

31. Zhan Y, Kim S, Izumi Y, Izumiya Y, Nakao T, Miyazaki H, Iwao H: Role of JNK, p38, and ERK in platelet-derived growth factorinduced vascular proliferation, migration, and gene expression. Arterioscler Thromb Vasc Biol 2003, 23:795-80I.

32. Izumi $Y$, Kim S, Namba M, Yasumoto H, Miyazaki H, Hoshiga M, Kaneda Y, Morishita R, Zhan Y, Iwao H: Gene transfer of dominant-negative mutants of extracellular signal-regulated kinase and c-Jun NH2-terminal kinase prevents neointimal formation in balloon-injured rat artery. Circ Res 200I, 88: $1120-1126$.

33. Sajid M, Lele M, Stouffer GA: Autocrine thrombospondin partially mediates TGF- $\beta$ I- induced proliferation of vascular smooth muscle cells. Am J Physiol Heart Circ Physiol 2000, 279: $\mathrm{H} 2159-\mathrm{H} 2165$

34. Miao H, Li S, Hu YL, Yuan S, Zhao Y, Chen BP, Puzon-McLaughlin W, Tarui T, Shyy JY, Takada Y, Usami S, Chien S: Differential regulation of Rho GTPases by $\beta I$ and $\beta 3$ integrins: the role of an extracellular domain of integrin in intracellular signaling. Cell Sci 2002, I 15:2199-2206.

35. Nadruz W Jr, Corat MA, Marin TM, Guimaraes Pereira GA, Franchini KG: Focal adhesion kinase mediates MEF2 and c-Jun activation by stretch: role in the activation of the cardiac hypertrophic genetic program. Cardiovasc Res 2005, 68:87-97.

36. Takino T, Nakada M, Miyamori H, Watanabe Y, Sato T, Gantulga D, Yoshioka K, Yamada KM, Sato H: JSAPI/JIP3 cooperates with focal adhesion kinase to regulate c-Jun $\mathrm{N}$-terminal kinase and cell migration. J Biol Chem 2005, 280:37772-3778I.

37. Vomastek T, Iwanicki MP, Schaeffer HJ, Tarcsafalvi A, Parsons JT, Weber MJ: RACKI targets the extracellular signal-regulated kinase/mitogen-activated protein kinase pathway to link integrin engagement with focal adhesion disassembly and cell motility. Mol Cell Biol 2007, 27:8296-8305.

38. Coller BS: Development of GP IIb/IIla antagonists. In Platelet glycoprotein Ilb/llla inhibitors in cardiovascular disease Edited by: Lincoff AM, Topol EJ. Humana Press, Totowa, N]; 1999.
Publish with BioMed Central and every scientist can read your work free of charge

"BioMed Central will be the most significant development for disseminating the results of biomedical research in our lifetime. "

Sir Paul Nurse, Cancer Research UK

Your research papers will be:

- available free of charge to the entire biomedical community

- peer reviewed and published immediately upon acceptance

- cited in PubMed and archived on PubMed Central

- yours - you keep the copyright
BioMedcentral 